\title{
PENDIDIKAN KEWARGANEGARAAN \\ UNTUK MEMBANGUN WAWASAN GLOBAL WARGA NEGARA MUDA
}

\author{
Mukhamad Murdiono \\ Fakultas Ilmu Sosial Universitas Negeri Yogyakarta \\ email: mukhamad_murdiono@uny.ac.id
}

\begin{abstract}
Abstrak: Penelitian ini bertujuan untuk menemukan nilai-nilai dasar yang perlu dikembangkan dalam pendidikan kewarganegaraan untuk membangun wawasan global warga negara muda. Penelitian menggunakan pendekatan kualitatif dengan metode grounded theory. Sumber data terdiri atas sumber kepustakaan dan responden yang dipilih dengan menggunakan metode purposive sampling.Teknik pengumpulan data menggunakan studi dokumentasi, wawancara, dan observasi. Analisis data menggunakan analisis induktif. Hasil penelitian menunjukkan bahwa nilai-nilai dasar yang perlu dikembangkan dalam pendidikan kewarganegaraan untuk membangun wawasan global warga negara muda dalam konteks Indonesia antara lain adalah ketuhanan, kemanusiaan, persatuan, kerakyatan, keadilan sosial, kompetisi, menghormati orang lain, kemerdekaan, dan perdamaian.
\end{abstract}

Kata Kunci: pendidikan kewarganegaraan, wawasan global, warga negara muda

\section{CIVIC EDUCATION TO BUILD YOUNG CITIZENS’ GLOBAL INSIGHT}

\begin{abstract}
This study was aimedtofind thebasic valueswhich needed tobe developedin civic education to build young citizens' global insight. This study utilized the qualitative apporach with the grounded theory method. The data source consisted of literature and respondents selected using the purposive sampling method. The data were collected using the documentation, interviews, and observations. The data were analyzed using the inductive analysis. The findings showed that the basic values which needed tobe developed in civic education to build a global insight of young citizens in the context of Indonesia include: divinity, humanity, unity, democracy, social justice, competition, respect for others, freedom, and peace.
\end{abstract}

Keywords: civic education, global insight, young citizens

\section{PENDAHULUAN}

Globalisasi yang terus berkembang dan terjadi hampir di seluruh negara di dunia, ditandai dengan kemajuan di berbagai bidang kehidupan manusia, termasuk kemajuan di bidang teknologi. Kemajuan di bidang teknologi, terutama teknologi komunikasi dan informasi, menjadikan dunia tempat berpijak semakin tanpa batas (borderless). Peristiwa yang terjadi di suatu negara dapat dengan mudah diketahui oleh seseorang yang berada di negara lain. Informasi dengan cepat mengalir ke berbagai belahan dunia dengan bantuan teknologi internet. Penggunaan teknologi internet memudahkan orang di seluruh penjuru planet bumi untuk mengakses informasi tanpa mengenal batas waktu dan wilayah. Internet dapat berperan dalam pertukaran informasi dan ide-ide antara pe- merintah dan warga negara (Kim dkk, 2011: 809). Dunia yang tanpa batas di era global tidak hanya menyebabkan informasi yang datang dari negara lain dapat dengan mudah masuk ke suatu negara, tetapi juga sebagai tantangan yang harus dihadapi oleh setiap negara.

Informasi yang datang silih berganti memiliki dampak terhadap kehidupan warga negara di dunia. Ideologi, gaya hidup, dan keyakinan atau kepercayaan yang berkembang di suatu negara dapat mempengaruhi kebiasaan dan pola-pola kehidupan yang sudah mapan di negara lain. Nilai-nilai dasar dalam bentuk ideologi bangsa yang telah lama dijadikan sebagai landasan bagi kehidupan warga negara perlahan mulai terkikis. Gejala mulai terkikisnya nilai-nilai dasar ini sangat kentara dari perilaku yang ditunjukkan generasi muda. Perilaku 
yang menjadi kecenderungan global, seperti gaya hidup yang hedonis dan konsumtif sangat mudah ditiru oleh generasi muda. Apabila perilaku imitatif berlebihan terhadap kecenderungan global dibiarkan, tidak menutup kemungkinan nilai-nilai dasar itu dapat luntur dan pudar.

Kecenderungan dan gaya hidup yang berkembang di negara maju akan diikuti oleh negara-negara yang sedang berkembang. Pola hidup konsumerisme dan hedonistik yang tumbuh subur di masyarakat Barat dengan budaya individualisme, perlahan mencemari budaya luhur bangsa-bangsa Timur yang terkenal santun dan memiliki semangat kolektivisme kuat. Globalisasi yang terus berkembang di abad ke-21 memengaruhi setiap aspek kehidupan masyarakat, termasuk keyakinan, norma-norma, nilai-nilai, dan perilaku, serta ekonomi dan perdagangan (Banks, 2008:132). Persoalan kecenderungan global yang dapat mengikis nilai-nilai luhur bangsa perlu dihadapi dan diberikan jalan keluar. Salah satu cara yang dapat dilakukan adalah dengan penguatan nilai-nilai luhur bangsa yang dijadikan sebagai landasan dalam kehidupan berbangsa dan bernegara melalui jalur pendidikan, khususnya pendidikan kewarganegaraan.

Perkembangan teknologi informasi dan komunikasi di era global abad ke-21 telah mengubah dunia begitu cepat. Perubahanperubahan itu telah memunculkan berbagai permasalahan yang tidak hanya dialami oleh satu negara, tetapi juga menjadi masalah lintas negara. Penelitian Karsten dkk. (1998:94) menemukan setidaknya ada 19 kecenderungaan global yang perlu diantisipasi oleh setiap negara. Tujuh di antaranya diidentifikasi sebagai kecenderungan yang tidak diinginkan, tapi sangat mungkin akan terjadi. Kewarganegaraan berkembang menjadi kewarganegaraan global (global citizenship) yang dapat dipahami sebagai konstruksi multidimensi yang bergantung pada saling keterkaitan antara dimensi tanggungjawab sosial, kompetensi global, dan keterlibatan warga negara secara global (Morais dan Ogden, 2011: 449).

Kecenderungan global yang terjadi perlu diberikan prioritas tertinggi dan membutuhkan perhatian besar dari para pembuat kebijakan di setiap negara. Karsten dkk. (1998:94) mengemukakan bahwa tujuh kecenderungan global yang perlu diantisipasi oleh setiap negara antara lain: (1) kesenjangan ekonomi antar negara akan semakin meluas secara signifikan; (2) informasi teknologi secara dramatis akan mengurangi privasi individu; (3) peningkatan perbedaan antara mereka yang memiliki dan tidak memiliki akses terhadap teknologi informasi; (4) konflik kepentingan antara negara maju dan berkembang akan meningkat; (5) biaya untuk memperoleh air bersih akan naik secara dramatis karena pertumbuhan penduduk dan kerusakan lingkungan; (6) penggundulan hutan secara dramatis akan mempengaruhi keragaman kualitas hidup; dan (7) pertumbuhan penduduk di negara berkembang akan menyebabkan peningkatan populasi terutama anak-anak yang hidup dalam kemiskinan. Kecenderungan-kecenderungan tersebut perlu diantisipasi oleh para pembuat kebijakan di suatu negara.

Memasuki paruh awal abad ke-21, setiap negara di dunia akan menghadapi berbagai permasalahan global yang perlu ditangani dengan serius. Cogan (1998:7) menegaskan bahwa setidaknya ada tiga permasalahan global utama yang dihadapi negara-negara di seluruh dunia. Ketiga permasalahan itu meliputi: (1) berkembangnya ekonomi global; (2) semakin pesatnya kemajuan teknologi dan komunikasi; dan (3) meningkatnya populasi penduduk dunia yang diikuti dengan munculnya permasalahan lingkungan. Pendapat senada dikemukakan Titus (1999:133) yang menyatakan bahwa dunia semakin kompleks dan saling terkait. Kompleksitas itu memunculkan serangkaian persoalan lintas negara, seperti penolakan dan pengaturan senjata nuklir, polusi lingkungan yang mendunia, dan munculnya kekuatan ekonomi dunia yang saling terkait.

Permasalahan-permasalahan global lintas negara yang muncul sebagai akibat gempuran globalisasi dan kemajuan teknologi yang begitu pesat memerlukan pemecahan melalui pendekatan baru dalam pendidikan kewarganegaraan. Pendekatan baru ini disebut Charles Titus sebagai civic education untuk pemahaman global, 
yaitu berupa cara pandang dan dedikasi baru pada pendidikan kewarganegaraan. Pendekatan ini pernah diujicobakan oleh Boulding (Titus, 1999:131-132) di Amerika dengan kesimpulan bahwa warga Amerika mengakui sebagai penduduk planet yang menjadi desa buwana (global village). Keadaan seperti ini mensyaratkan perhatian dan aksi warga negara pada skala lintas negara dan lintas budaya. Dengan demikian, jelas perlu ada perspektif baru dalam mengembangkan budaya yang disebut Boulding (1988) sebagai "global civic culture" atau yang sekarang biasa dikenal dengan "transnational civil society” (Parker dkk, 1999: 130).

Pendidikan kewarganegaraan memiliki peran strategis dalam membangun wawasan global warga negara. Pendidikan kewarganegaraan tidak sebatas mempelajari hak dan kewajiban warga negara, melainkan lebih luas dan mendalam termasuk mempersiapkan warga negara menjadi warga global. Pendidikan kewarganegaraan membekali peserta didik di sekolah dengan pengetahuan tentang isu-isu global, budaya, lembaga dan sistem internasional dan merupakan indikasi dari pendekatan minimalis yang bisa mengambil tempat secara eksklusif di dalam kelas. Osler dan Starkey (Bourke dkk, 2012:163) mengemukakan bahwa pendidikan kewarganegaraan mencerminkan pendekatan maksimal yang bertujuan untuk memastikan peserta didik siap untuk mengambil peran sebagai warga global dewasa dan bertanggung jawab.

Warga negara muda atau generasi muda memiliki peran penting dalam pergaulan internasional. Di dunia, ada banyak forum atau organisasi internasional yang didirikan oleh para pemuda. Forum atau organisasi itu dibentuk sebagai wadah untuk melakukan kegiatan kepemudaan tingkat internasional. Pendirian forum kepemudaan internasional itu sesuai dengan tujuannya masing-masing. Misalnya ada forum pemuda internasional Seliger, Rusia (Seliger Youth Forum), forum pemuda internasional untuk kebijakan, perubahan, dan pembangunan di India (International Youth Forum for Policy, Change, and Development), Forum Pemuda Asia (Asian Youth Forum), dan lain-lain. Ke- terlibatan generasi muda Indonesia dalam forum-forum kepemudaan internasional harus dibekali dengan berbagai pengetahuan atau wawasan global. Salah satu cara yang dapat dilakukan yaitu mengembangkan wawasan global warga negara muda melalui pendidikan kewarganegaraan di sekolah.

Pendidikan kewarganegaraan untuk membangun wawasan global sangat diperlukan bagi peserta didik sebagai warga negara muda. Agbaria (2011:61-62) menjelaskan pentingnya pendidikan global untuk membangun wawasan global warga negara di era global. Generasi muda akan menghadapi tatanan dunia baru. Kontak sehari-hari mereka mencakup individu dari beragam etnis, jenis kelamin, bahasa, ras, dan latar belakang sosial ekonomi. Mereka akan mengalami beberapa masalah yang serius seperti: kesehatan, ketidakadilan, kerusakan lingkungan, ledakan penduduk, migrasi transnasional, nasionalisme etnis, dan penurunan negarabangsa. Semua anak, tanpa memandang tempat kelahiran, memiliki hak untuk mendapatkan pendidikan. Tetapi, anak-anak yang berhasil menyelesaikan pendidikan (lulusan) di abad ke21 harus dilengkapi dengan sikap, pengetahuan, dan keterampilan yang mereka butuhkan untuk menjadi warga negara yang kompeten, bertanggung jawab dan manusiawi.

Pendidikan kewarganegaraan harus dikembangkan agar mampu membekali warga negara muda dengan pemahaman global yang memadai. Banks (2008:135) mengemukakan bahwa perlu ada konsepsi ulang terhadap pendidikan kewarganegaraan di abad ke-21 agar mampu secara efektif mendidik peserta didik menjadi warga negara yang berfungsi. Agar reformulasi berhasil, pengetahuan yang mendasari konstruksi harus bergeser dari mainstream pengetahuan akademik menuju pengetahuan akademik transformatif. Mainstream pengetahuan memperkuat pengetahuan tradisional dan ilmu-ilmu sosial mapan serta perilaku dan pengetahuan yang dilembagakan dalam budaya populer, baik di sekolah-sekolah maupun perguruan tinggi.

Salah satu tujuan penting dari pengetahuan transformatif adalah untuk meningkatkan 
kemampuan manusia sebagai warga negara global. Pendidikan kewarganegaraan transformatif mengakui dan memvalidasi identitas budaya siswa. Hal ini berakar pada pengetahuan akademis transformatif dan memungkinkan siswa memperoleh informasi, keterampilan, dan nilainilai yang diperlukan untuk melawan ketidaksetaraan dalam masyarakat, bangsa, dan dunia. Selain itu, untuk mengembangkan nilai-nilai dan perspektif kosmopolitan dan mengambil tindakan menciptakan keadilan dalam komunitas masyarakat multikultural demokratis. Hal ini mendorong keterampilan berpikir kritis yang disebut oleh DeJaeghere sebagai pendidikan kewarganegaraan kritis (Banks, 2008:135).

Penelitian yang dilakukan Bourke dkk. (2012:164) menunjukkan bahwa peserta didik yang memiliki kesadaran tinggi cenderung dapat diandalkan, lebih hati-hati, teliti, bertanggung jawab, terorganisasi, berorientasi pada prestasi dan selalu siap sebagai warga negara. Lebih lanjut, Bourke dkk. menambahkan bahwa mereka yang memiliki keramahan tinggi pada umumnya dianggap baik hati, fleksibel, kooperatif, peduli, sopan, percaya diri dan toleran. Pengalaman-pengalaman yang diperoleh peserta didik dapat menjadi bekal mereka untuk membentuk kepribadian sebagai warga dunia. Penelitian sejenis yang dilakukan Gainous dan Martens (2012:253) juga membuktikan bahwa pendidikan kewarganegaraan terbukti efektif untuk membangun kompetensi politik dan warga negara muda yang demokratis dan bertanggungjawab.

Untuk membangun wawasan global warga negara muda, pendidikan kewarganegaraan lebih menekankan pada pengembangan peserta didik agar memiliki sikap dan kemauan melakukan interaksi dengan sesama manusia yang mendasarkan pada prinsip-prinsip menjaga harkat dan martabat manusia sebagai mahluk yang paling mulia. Ada dua prinsip yang mendasari prinsip-prinsip moral yang akan dikembangkan sebagai warga negara, yaitu simpati dan respek. Simpati merupakan nilai-nilai dan sikap yang dimiliki seseorang untuk selalu memberikan perhatian kepada orang lain, terutama jika dalam keadaan yang tidak lebih baik dari diri kita.
Respek dimaknai sebagai kemampuan seseorang untuk menjaga diri sendiri dari perbuatan yang dapat merugikan atau mengganggu hakhak yang dimiliki oleh orang lain (Zamroni, 2007:127). Dengan demikian, pengembangan pendidikan kewarganegaraan selain menekankan pada aspek pengetahuan, nilai-nilai, dan sikap juga harus menumbuhkan respek dan empati yang bersifat global, melewati batasbatas bangsa dan negara.

Dari uraian permasalahan yang telah dikemukakan, peneliti tertarik untuk melakukan kajian mendalam melalui penelitian tentang nilai-nilai dasar apa saja yang perlu dikembangkan dalam pendidikan kewarganegaraan untuk membangun wawasan global warga negara muda. Mengembangkan kerangka konseptualfilosofis tentang pendidikan kewarganegaraan global merupakan langkah mendesak dan strategis sebagai bagian dari pengembangan dasar pijakan bagi pembuatan kebijakan pendidikan berwawasan global secara lebih luas. Selama ini, penelitian yang terkait dengan pendidikan kewarganegaraan global jarang dilakukan. Hasil kajian melalui penelitian diharapkan akan memperkaya baik secara teoretis maupun praktis dalam mengembangkan pendidikan kewarganegaraan berwawasan global.

\section{METODE}

Penelitian ini menggunakan pendekatan kualitatif dengan metode grounded theory. Peneliti yang menggunakan pendekatan kualitatif menekankan pada hakikat realitas sosial yang dibangun berdasarkan keadaan yang senyatanya terjadi. Peneliti dan apa yang diteliti memiliki hubungan yang sangat dekat (Denzin dan Lincoln, 2005:10; Flick dkk., 2004:3). Penelitian kualitatif sering juga disebut sebagai penelitian naturalistik. Sebab situasi lapangan penelitian bersifat natural atau wajar, sebagaimana adanya tanpa dimanipulasi atau diatur dengan eksperimen atau tes (Denzin dan Lincoln, 2005:3; Nasution, 1988:18). Oleh karena itu, informasi yang diperoleh adalah peristiwa dari situasi yang alamiah tentang nilai-nilai dasar yang perlu dikembangkan dalam pendidikan kewarganegaraan untuk membangun wawasan global 
warga negara muda. Penggunaan metode grounded theory dalam penelitian ini dikarenakan datanya bersifat deskriptif, bertujuan untuk menggambarkan realitas, dan berupaya untuk menemukan teori yang dibangun dari data. Peneliti yang menggunakan metode ini berharap bahwa teori yang ditemukan berkaitan dengan teori lain dalam bidang mereka masingmasing secara kumulatif, sehingga implikasi dari teori tersebut akan membawa manfaat (Strauss dan Corbin, 2009: 12).

Untuk kepentingan analisis dalam penelitian, sumber data dibagi menjadi dua kategori, yaitu: pertama, sumber bahan cetak (kepustakaan), meliputi buku teks, dokumen-dokumen kurikulum, jurnal, makalah, kliping, surat kabar, tabloid, dan lain-lain yang berkaitan dengan pendidikan kewarganegaraan untuk membangun wawasan global warga negara muda. Kedua, sumber responden (human resources), dipilih menggunakan metode purposive sampling, yang terdiri dari pakar pendidikan kewarganegaraan, pakar politik internasional/perspektif global, pakar filsafat, dan pakar sejarah. Teknik pengumpulan data yang digunakan dalam penelitian ini antara lain: studi dokumentasi, wawacara, dan observasi. Penelitian ini menggunakan analisis induktif, yakni proses pembahasannya meliputi pola-pola, tema-tema dan kategori-kategori yang berasal dari data, bukan ditentukan sebelum pengumpulan dan analisis data. Analisis data dalam penelitian ini mengikuti langkah-langkah yang dikembangkan oleh Miles dan Huberman (1992:20) yang terdiri atas tiga alur kegiatan yang dilakukan secara bersamaan, yaitu: reduksi data, penyajian data, dan penarikan kesimpulan.

\section{HASIL DAN PEMBAHASAN}

Berdasarkan data penelitian yang diperoleh di lapangan, terlihat bahwa ada beberapa nilai dasar dalam pendidikan kewarganegaraan untuk membangun wawasan global warga negara muda. Nilai-nilai dasar inilah yang dijadikan sebagai pijakan dalam pengembangan pendidikan kewarganegaraan global. Nilai-nilai dasar yang dikembangkan dalam pendidikan kewarganegaraan global bertujuan untuk mem- bentuk warga negara yang memiliki berbagai karakteristik yang diperlukan di era global. Warga negara yang hidup di era global abad ke21 akan menghadapi permasalahan-permasalahan yang semkain kompleks baik dalam skala lokal maupun global.

Dua nilai dasar penting yang perlu dikembangkan dalam pendidikan kewarganegaraan global, yakni keadilan sosial dan semangat berkompetisi. Keadilan sosial penting untuk dikembangkan karena tidak menutup kemungkinan di era global ketimpangan akan semakin nyata. Tidak bisa dimungkiri bahwa kemiskinan menjadi salah satu masalah besar yang dihadapi sejumlah negara di dunia. Oleh karena itu, perlu ada upaya untuk menciptakan keadilan sosial dan kesejahteraan yang merata untuk semua umat manusia di atas muka bumi.

Semangat untuk berkompetisi perlu dikembangkan karena di era global persaingan, terutama di bidang ekonomi, akan semakin ketat. Jika kita tidak bisa berkompetisi dengan negara lain, hanya akan menjadi objek. Warga negara global harus memiliki semangat dan kemampuan untuk berkompetisi dalam berbagai bidang. Di bidang ekonomi, globalisasi ditandai dengan pasar terbuka (open market) yang dapat dimasuki oleh siapa saja. Pasar yang semakin terbuka memudahkan setiap orang atau negara terlibat dalam persaingan ekonomi. Dalam mengembangkan semangat berkompetisi di era global, kita harus tetap bersandar pada Pancasila sebagai filosofi bangsa.

Temuan penelitian yang lain menunjukkan bahwa dalam konteks pendidikan kewarganegaraan global yang dikembangkan di Indonesia, nilai-nilai yang dikembangkan mengacu pada nilai-nilai Pancasila sebagai dasar negara. Semua nilai yang ada dalam Pancasila dapat dijadikan sebagai landasan dalam pengembangan pendidikan kewarganegaraan global di Indonesia. Nilai ketuhanan, kemanusiaan, persatuan, kerakyatan, dan keadilan dapat dijadikan sebagai pijakan dalam pergaulan internasional. Nilai-nilai Pancasila dapat dijadikan sebagai jangkar transendental bagi warga negara Indonesia, yakni nilai-nilai yang dijadikan seba- 
gai pegangan dan dasar pijakan dalam kehidupan sehari-hari.

Selain itu, pendidikan kewarganegaraan global yang dikembangkan di Indonesia harus mengacu pada konstitusi negara atau bisa disebut sebagai nilai-nilai konstitusional. Dalam konstitusi negara Indonesia jelas disebut ada nilai-nilai hubungan antarnegara. Pembukaan UUD 1945 secara jelas menyatakan bahwa tujuan berdirinya negara Republik Indonesia salah satunya adalah "ikut melaksanakan ketertiban dunia yang berdasarkan kemerdekaan, perdamaian abadi, dan keadilan sosial". Dengan demikian jelas bahwa konstitusi kita membuka peluang untuk mengembangkan nilai-nilai hubungan antarnegara yang didalamnya memuat nilai kemerdekaan, perdamaian, dan keadilan sosial.

Temuan penelitian seperti telah dikemukakan, mendukung penelitian sebelumnya yang dilakukan Morais dan Ogden (2011) yang menemukan tentang dimensi-dimensi kewarganegaraan global yang dapat dikembangkan dalam pembelajaran kewarganegaraan di sekolah. Siswa berlatih dan belajar bersama guru dan temannya untuk mengembangkan dimensidimensi kewarganegaraan global agar siap menjadi warga negara global yang cerdas dan berkarakter. Ada tiga dimensi utama yang sering disebut dalam kewarganegaraan global, yakni tanggungjawab sosial (social responsibility), kompetensi global (global competence), dan keterlibatan dalam kewargaan global (global civic engagement). Ketiga dimensi kewarganegaraan global ini dapat dijelaskan sebagai berikut.

Pertama, tanggung jawab sosial (social responsibility) dimaknai sebagai tingkat kesadaran saling ketergantungan dan kepedulian sosial kepada orang lain, masyarakat, dan lingkungan. Siswa dapat berlatih mengembangkan tanggung jawab sosial dengan cara ikut serta mengevaluasi masalah-masalah sosial dan mengidentifikasi kasus atau contoh-contoh ketidakadilan dan kesenjangan global. Selain itu, siswa berlatih menghormati perbedaan dan membangun etika pelayanan sosial untuk mengatasi isu-isu global dan lokal. Mereka memahami keterkaitan antara perilaku lokal dan kon- sekuensi global. Siswa ditumbuhkan kesadarannya bahwa di era global mereka akan bertemu dan berkomunikasi dengan orang lain yang memiliki latar belakang yang berbeda. Perbedaan itu bukan hanya dalam hal budaya yang ada di satu negara, tetapi sudah melintasi batas-batas wilayah negara (transnational).

Sebagai warga negara global, siswa berlatih untuk memiliki tanggungjawab sosial yang sangat diperlukan di era global. Dimensi tanggung jawab sosial dapat dikembangkan dalam pembelajaran kewarganegaraan dengan memelajari beberapa permasalahan penting, antara lain kesenjangan dan keadilan global (global justice and disparities), empati dan peduli (altruism and empathy), tanggung jawab pribadi dan saling keterkaitan global (global interconnectedness and personal responsibility). Melalui pembelajaran dialogis-kritis, siswa dilatih dan dikembangkan tanggungjawabnya sebagai warga negara. Semua perilaku yang dilakukan, baik dalam skala lokal maupun global, harus mampu dipertanggungjawabkan.

Kedua, kompetensi global (global competence) yang diartikan sebagai kemampuan memiliki pikiran yang terbuka dan secara aktif berusaha memahami norma-norma budaya orang lain dan memanfaatkan pengetahuan yang dimiliki untuk berinteraksi, berkomunikasi, dan bekerja secara efektif. Menghadapi dunia global yang berubah dengan cepat, siswa perlu memiliki kompetensi global. Sebagai warga negara muda, siswa memiliki kesempatan yang luas untuk belajar dan berlatih mengembangkan pemahaman global. Dimensi kompetensi global dapat dikembangkan dalam pembelajaran pendidikan kewarganegaraan dengan menggunakan pendekatan berpikir kritis.

Dimensi kompetensi global dapat dipelajari siswa dengan mempelajari beberapa permasalahan penting, antara lain kesadaran diri (selfawareness), komunikasi antarbudaya (intercultural communication), dan pengetahuan global (global knowledge). Siswa menyadari keterbatasan diri mereka sendiri dan kemampuan untuk terlibat dalam pertemuan antarbudaya. Siswa sebagai bagian dari warga dunia, akan bertemu atau bersentuhan dengan budaya lain. Di era 
global, siswa juga harus menunjukkan keterampilan komunikasi antarbudaya dan memiliki kemampuan untuk terlibat dalam pertemuan antarbudaya. Selain itu, siswa perlu menunjukkan minat dan pengetahuan tentang isu-isu dan peristiwa-peristiwa yang terjadi di dunia. Peristiwa yang terjadi di suatu negara, dengan bantuan teknologi internet, sangat mudah dan cepat menjadi isu utama di negara lain.

Ketiga, keterlibatan dalam kewargaan global (global civic engagement) yang dimaknai sebagai tindakan dan atau kecenderungan untuk mengenali masalah-masalah kemasyarakatan baik di tingkat lokal, regional, nasional, maupun global dan menanggapinya melalui tindakan seperti kesukarelaan, aktivitas politik, dan partisipasi masyarakat. Siswa sebagai warga negara muda perlu dikembangkan kemampuannya untuk berpartisipasi secara aktif dalam mengidentifikasi dan menyelesaikan berbagai permasalahan global yang muncul. Keterlibatan dalam hidup kewargaan merupakan salah satu unsur penting dari modal sosial (social capital).

Siswa dapat berlatih berpartisipasi dalam kewargaan global dengan belajar tentang beberapa masalah global, antara lain keterlibatan dalam organisasi kemasyarakatan, aspirasi politik, dan aktivisme warga negara global. Keterlibatan dalam organisasi kemasyarakatan global dapat dilakukan siswa dengan cara terlibat atau berkontribusi untuk bekerja secara sukarela atau membantu organisasi sipil global. Siswa dapat membangun aspirasi politik mereka dengan menyintesiskan pengetahuan dan pengalaman global dalam domain publik. Aspirasi dapat berbentuk kritik terhadap kebijakan publik yang dikeluarkan pemerintah. Sementara itu, aktivisme warga negara global dapat dilakukan siswa melalui keterlibatan dalam perilaku bermanfaat yang dapat memajukan agenda global.

Tiga dimensi global yang telah dijelaskan di atas, menjadi nilai-nilai dasar yang penting untuk dikembangkan dalam pendidikan kewarganegaraan global. Keterampilan-keterampilan hidup yang didapatkan siswa melalui pembelajaran kewarganegaraan sangat bermanfaat dalam kehidupan bermasyarakat. Keterampilan seperti tanggung jawab sosial, kompetensi se- bagai warga negara global, dan keterlibatan dalam aktivitas politik merupakan bagian penting yang harus dikembangkan. Agar siswa dapat menguasai keterampilan-keterampilan hidup sebagai warga negara seperti telah disebutkan, pembelajaran kewarganegaraan yang dikembangkan di sekolah perlu menerapkan pendekatan dan strategi pembelajaran yang tepat. Strategi pembelajaran kewarganegaraan yang dapat diterapkan untuk mengembangkan keterampilan hidup siswa sebagai warga negara antara lain melalui strategi dialogis-kritis.

Temuan penelitian terkait nilai-nilai dalam pendidikan kewarganegaraan global juga senada dengan pendidikan kewarganegaraan global yang dikembangkan Oxfam (2006). Dalam kurikulum pendidikan kewarganegaraan yang dikembangkan Oxfam, ada tiga kunci utama untuk mengembangkan pendidikan kewarganegaraan global, yang meliputi pengetahuan dan pemahaman, keterampilan, serta nilai dan sikap. Ketiga kunci utama dalam pendidikan kewarganegaraan global dikembangkan ke dalam tema-tema atau topik-topik yang disesuaikan dengan usia siswa.

Pengetahuan dan pemahaman yang dikembangkan dalam pendidikan kewarganegaraan global antara lain meliputi: keadilan sosial dan persamaan, keberagaman, globalisasi dan saling ketergantungan, pembangunan berkelanjutan, perdamaian dan konflik. Tema-tema untuk mengembangkan pengetahuan dan pemahaman siswa tentang pendidikan kewarganegaraan global dijabarkan lebih rinci lagi ke dalam subtema yang disesuaikan dengan tingkat usia siswa.

Keterampilan yang dikembangkan dalam pendidikan kewarganegaraan global antara lain meliputi berpikir kritis, kemampuan untuk mengemukakan pendapat secara efektif, kemampuan untuk melawan ketidakadilan, memiliki rasa hormat terhadap orang dan lingkungan, dan kerjasama serta resolusi konflik. Berbagai keterampilan ini dijabarkan ke dalam tema-tema pembelajaran yang dikembangkan sesuai dengan tingkat kemampuan dan usia siswa. Keterampilan yang dikembangkan mulai dari ke- 
terampilan yang sederhana sampai pada keterampilan yang lebih kompleks.

Nilai dan sikap yang dikembangkan dalam pendidikan kewarganegaraan global antara lain meliputi: rasa identitas dan harga diri, empati, komitmen terhadap keadilan sosial dan kejujuran, menghormati keragaman, kepedulian terhadap lingkungan dan komitmen terhadap pembangunan berkelanjutan, dan keyakinan bahwa orang dapat menciptakan perbedaan. Nilai dan sikap yang dikembangkan dalam pendidikan kewarganegaraan global disesuaikan dengan karakteristik perkembangan dan usia siswa.

Dari pembahasan yang telah dikemukakan, menunjukkan bahwa nilai-nilai dasar utama dalam pendidikan kewarganegaraan untuk membangun wawasan global warga negara muda dalam konteks Indonesia antara lain: ketuhanan, kemanusiaan, persatuan, kerakyatan, keadilan sosial, kompetisi, menghormati orang lain, kemerdekaan, dan perdamaian. Sebagian nilai-nilai dasar utama dalam pendidikan kewarganegaraan global dalam konteks Indonesia merupakan nilai utama yang dimuat dalam Pancasila dan konstitusi negara Republik Indonesia.

\section{PENUTUP}

Dari penelitian yang telah dilakukan dapat disimpulkan bahwa ada nilai-nilai dasar utama yang perlu dikembangkan dalam pendidikan kewarganegaraan untuk membangun wawasan global warga negara muda. Nilai-nilai dasar yang perlu dikembangkan dalam pendidikan kewarganegaraan global dalam konteks Indonesia antara lain ketuhanan, kemanusiaan, persatuan, kerakyatan, keadilan sosial, kompetisi, menghormati orang lain, kemerdekaan, $n$ dan perdamaian. Nilai-nilai dasar ini penting untuk dikembangkan dalam rangka mengembangkan wawasan global warga negara muda agar dapat berperan secara efektif dalam kancah global tanpa meninggalkan jati diri sebagai bangsa Indonesia yang memiliki Pancasila sebagai falsafah dalam kehidupan berbangsa dan bernegara.

\section{UCAPAN TERIMA KASIH}

Peneliti mengucapkan terima kasih kepada Menteri Pendidikan dan Kebudayaan Republik Indonesia yang telah memberikan bantuan beasiswa BPPS untuk menyelesaikan penelitian dan studi program doktor. Artikel ini merupakan bagian dari disertasi peneliti untuk menyelesaikan program doktor Pendidikan Kewarganegaraan di Sekolah Pascasarjana Universitas Pendidikan Indonesia, Bandung.

\section{Daftar Pustaka}

Agbaria, A. K. 2011. "The Social Studies Education Discourse Community on Globalization: Exploring The Agenda of Preparing For The Global Age", dalam Journal of Studies in International Education, 15 (1), hlm. 57-74.

Banks, J. A. 2008. "Diversity, Group Identity, and Citizenship Education in A Global Age", dalam Educational Researcher, 37 (3), hlm. 129-139.

Bourke, L., Bamber, P., dan Lyons, M. 2012. "Global Citizens: Who Are They?", dalam Education, Citizenship and Social Justice, 7 (2), hlm. 161-174.

Cogan, J.J. 1998. "Citizenship Education for The 21st Century: Setting The Context", dalam Cogan, J.J dan Derricot, R. (eds.), Citizenship for The 21st Century: An International Perspective on Education. London: Kogan Page Limited. Hlm.

Denzin, N. K. dan Lincoln, Y. S. 2005. The Sage Handbook of Qualitative Research. California: Sage Publications.

Gainous, J. dan Martens, M. 2012. "The Effectiveness of Civic Education: Are "Good" Teachers Actually Good For "All" Students?", dalam American Politics Research, 40 (2), hlm. 232-266.

Flick, U., Kardorff, E., dan Steinke, I. 2004. "What Is Qualitative Research? An 
Introduction To The Field", dalam Flick, U., Kardorff, E.V., dan Steinke, I. (eds.), A Companion to Qualitative Research. London: Sage Publications. Hlm. 3-11

Karsten, S., et al. 1998. "Challenges Facing The 21St Century Citizen: Views of Policy Makers", dalam Cogan, J.J dan Derricot, R. (eds.), Citizenship for The 21st Century: An International Perspective on Education. London: Kogan Page Limited. Hlm.

Kim, B. J., Kavanaugh, A. L., \& Hult, K. M. 2011. "Civic Engagement and Internet Use in Local Governance: Hierarchial Linear Models for Understanding The Role of Local Community Groups", dalam Administration \& Society, 43 (7), hlm. 807-835.

Miles, M. B. dan Huberman, A. M. 1992. Analisis Data Kualitatif: Buku Sumber tentang Metode-metode Baru, alih bahasa T. R. Rohidi. Jakarta: UI Press.

Morais, D.B. dan Ogden, A.C. 2011. Initial Development and Validation of The Global Citizenship Scale, dalam Journal of Studies in International Education, 15 (5), hlm. 445-446.
Nasution, S. 1988. Metode Penelitian Naturalistik-Kualitatif. Bandung: Tarsito.

Oxfam 2006. Education for Global Citizenship: A Guide for Schools. Oxford: Oxfam Development Education.

Parker, W.C., Ninomiya, A., dan Cogan, J. 1999. "Educating World Citizens: Toward Multinational Curriculum Development", dalam American Educational Research Journal, 36 (2), hlm. 117-145.

Straus, A. dan Corbin, J. 2009. Dasar-Dasar Penelitian Kualitatif: Tatalangkah dan Teknik-Teknik Teoritisasi Data, alih bahasa M. Shodiq dan I. Muttaqien. Yogyakarta: Pustaka Pelajar.

Titus, C. 1999. Civic Education untuk Pemahaman Global, dalam Branson, M.S. dkk. (eds.), Belajar Civic Education Dari Amerika, alih bahasa Syafruddin, M.Y. Alimi, \& M. N. Khoiron. Yogyakarta: LKIS dan The Asia Foundation (TAF).

Zamroni. 2007. Pendidikan dan Demokrasi Dalam Transisi: Prakondisi Menuju Era Globalisasi. Jakarta: PSAP Muhammadiyah. 